\title{
The genetics of intracranial aneurysms
}

Received: 20 February 2006/ Accepted: 24 March 2006/Published online: 31 May 2006

(C) The Japan Society of Human Genetics and Springer-Verlag 2006

\begin{abstract}
The rupture of an intracranial aneurysm (IA) leads to a subarachnoid hemorrhage, a sudden onset disease that can lead to severe disability and death. Several risk factors such as smoking, hypertension and excessive alcohol intake are associated with subarachnoid hemorrhage. IAs, ruptured or unruptured, can be treated either surgically via a craniotomy (through an opening in the skull) or endovascularly by placing coils through a catheter in the femoral artery. Even though the etiology of IA formation is mostly unknown, several studies support a certain role of genetic factors. In reports so far, genome-wide linkage studies suggest several susceptibility loci that may contain one or more predisposing genes. Studies of several candidate genes report association with IAs. To date, no single gene has been identified as responsible for IA formation or rupture. The identification of susceptible genes may lead to the understanding of the mechanism of formation and rupture and possibly lead to the development of a pharmacological therapy.
\end{abstract}

Keywords Intracranial aneurysm - Subarachnoid hemorrhage Stroke Genome-wide linkage analysis · Candidate gene

\section{Introduction}

Subarachnoid hemorrhage (SAH) is still one of the most sudden and devastating diseases in the field of

B. Krischek $\cdot$ I. Inoue $(\bowtie)$

Division of Genetic Diagnosis, Institute of Medical Science, The University of Tokyo, 4-6-1 Shirokanedai, Minato-ku,

Tokyo 108-8639, Japan

E-mail: ituro@ims.u-tokyo.ac.jp

Tel.: + 81-3-54495325

Fax: $+81-3-54495765$

I. Inoue

CREST (Core Research for Evolutional Science

and Technology) of the Japan Science and Technology Agency, Kawaguchi, Japan neurovascular diseases. Its most frequent cause is the rupture of an intracranial aneurysm (IA), which is an outpouching or sac-like widening of a cerebral artery. Initial diagnosis is usually evident on a cranial computer tomography (CT) showing extravasated (hyperdense) blood in the subarachnoid space. In a second step, the gold standard of diagnostic techniques to detect the possible underlying ruptured aneurysm is intra-arterial digital subtraction angiography and additional threedimensional (3D) rotational angiography (panels A and $B$ in Fig. 1). Recently non-invasive diagnostic imaging modalities are becoming increasingly sophisticated. 3D CT angiography and 3D magnetic resonance angiography allow less invasive methods to reliably depict IAs (see panel C in Fig. 1).

Even though genetic factors are thought to play an important role in the pathogenesis of IA in addition to the well-published environmental factors (Juvela 2002; Wiebers et al. 2003), only recent progress in molecular genetics has enabled us to investigate the possible genetic determinants of this disease. Should it be possible to identify a genetic marker associated with an increased risk of formation and rupture of an IA, the necessity for screening and urgency of treatment could be determined more easily. Although a familial predisposition is the strongest risk factor for the development of IA, the mode of Mendelian inheritance is uncertain in most families. Therefore, multiple genetic susceptibilities are considered to act together in the etiology of IA. Accordingly, researchers applied non-parametric linkage study and case-control association studies for the genetic analysis of IA and thus far identified several genes to be susceptible to IA. Recently, two hypotheses, "common variant-common disease" and "rare variantcommon disease," are discussed for the susceptibility of common disease: most likely, both hypotheses are true, dependent on the type of disease. However, the approach to detect the causality is conceptually different in both hypotheses. We summarize the current knowledge of IA genetics and also discuss the method to detect the causalities. 
Fig. 1 Imaging of a right internal carotid aneurysm (arrow) with a a gold standard intra-arterial digital subtraction angiography and $\mathbf{b}$ a threedimensional $(3 \mathrm{D})$ rotational angiography. c A 3D magnetic resonance image, a noninvasive technique, performed with a 3-Tesla MRI depicts the aneurysm at high resolution

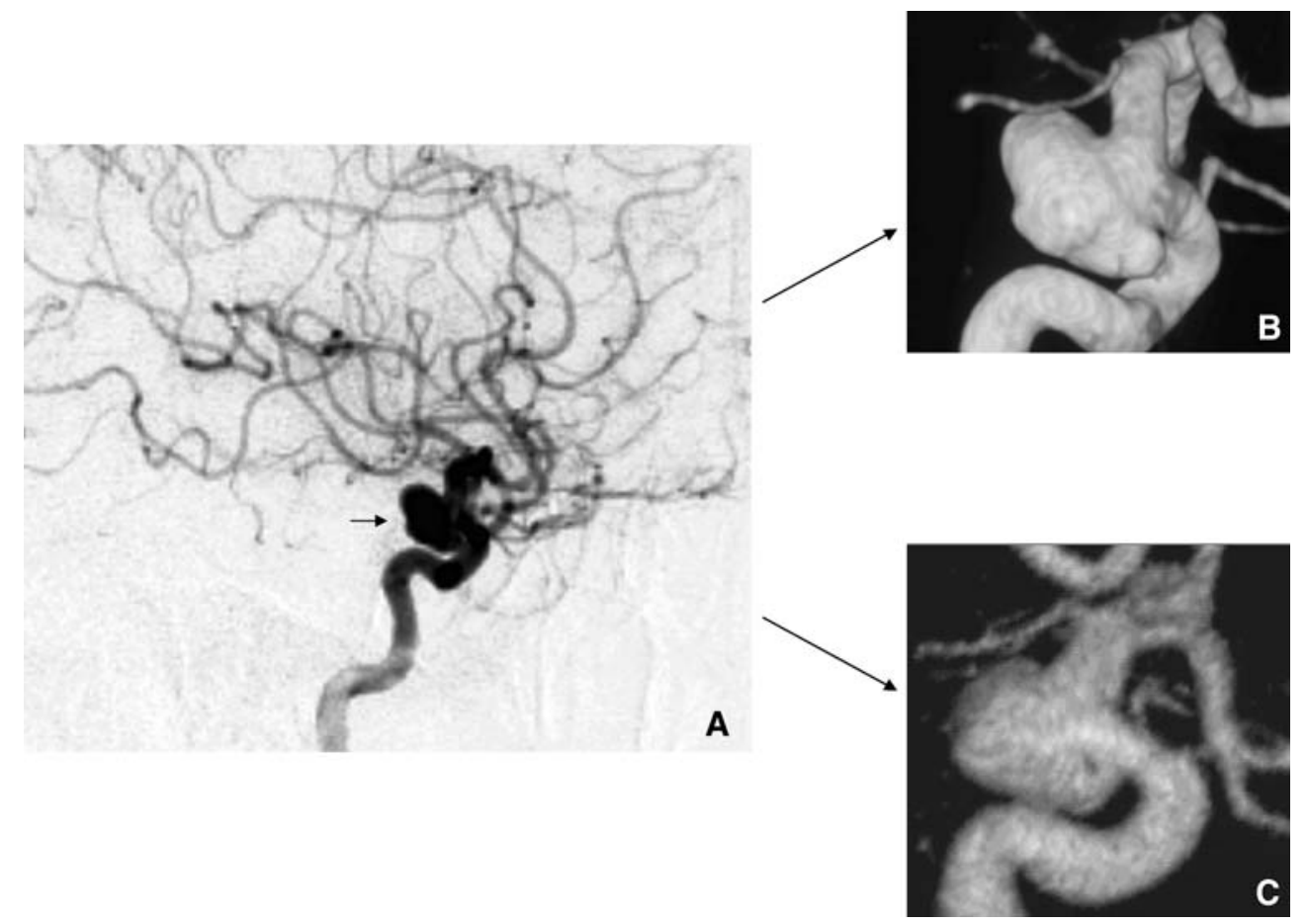

\section{Pathology, epidemiology and etiology}

Hemodynamic stress at arterial bifurcations are believed to contribute to aneurysm development (Ingebrigtsen et al. 2004). However, it is largely unknown why only some adults develop aneurysms at bifurcations and most do not. A number of contradictory observations led to the dispelling of the hypothesis of a congenital defect of a weak spot in the muscle layer of the arterial wall. Through this, the inner layers of the arterial wall would bulge and then form an aneurysm. But it was demonstrated that these gaps are equally common in patients with and without aneurysms (Stehbens 1989) and usually packed by dense collagen fibrils (Fujimoto 1996; Finlay et al. 1998). Furthermore, the defect in the muscle layer is located in the wall of the aneurysmal sac and not at the neck of the aneurysm (Stehbens 1989). Possibly the influence of the risk factors (mentioned below) leads to a thickening of the intimal layer and subsequently increases strain in the more elastic portions of the vessel wall (Crompton 1966). Structural abnormalities in structural proteins of the extracellular matrix have been identified in the arterial wall at a distance from the aneurysm itself. Computerized morphometric analysis has indicated that reticular fibers in the arterial media of cerebral arteries were significantly decreased in patients with aneurysms. In addition, these fibers were irregularly distributed and shortened when compared to those seen in control arteries (Chyatte et al. 1990). The exact etiology of IA formation remains unclear.

Subarachnoid hemorrhage occurs around 1.6 times more often in women than in men (Rinkel et al. 1998) and 2.1 times more often in blacks than whites
(Broderick et al. 1992). Further epidemiological studies demonstrate a strong genetic influence: Siblings have a sixfold increased risk of being struck by the same disease. In total, the risk is three to seven times higher in first-degree relatives of patients with SAH than in the general population (Bromberg et al. 1995; Schievink et al. 1995; Wang et al. 1995; De Braekeleer et al. 1996; Ronkainen et al. 1997). In second-degree relatives, the incidence of SAH is similar to that found in the general population (Bromberg et al. 1995). It has also been shown that the prevalence of unruptured IA is significantly higher $(10.5-13.5 \%)$ in a Japanese subgroup with a family history of IA (Nakagawa and Hashi 1994; Kojima et al. 1998). The prevalence of harboring an IA within the population aged over 30 years is between 3.6 and 6.5\% (Ujiie et al. 1993; Yamaki et al. 1994; Iwamoto et al. 1999; Wardlaw and White 2000). Especially in Japan, where a brain assessment system called "Braindock" systematically screens patients for incidental aneurysms, the incidence of unruptured IAs seems to be increasing with the continuous evolution of magnetic resonance angiography imaging techniques (Yoshimoto and Mizoi 1997; Morita et al. 2005). The annual incidence of SAH due to aneurysmal rupture has been reported to be 11/100,000 in the United States (Ingall et al. 1989), whereas the incidence observed in Japan depending on the region is between 14/100,000 (Inagawa et al. 1988) and 96/100,000 (Kiyohara et al. 1989). The risk of rupture depends on the size and location of the aneurysm (White and Wardlaw 2003; Wiebers et al. 2003). It has been reported to be $2.7 \%$ per year in a Japanese population (Morita et al. 2005) and 1.9\% in a white population (Rinkel et al. 1998). 


\section{Treatment}

Currently, the two main options of treatment are either microvascular surgical clipping or endovascular coiling of the aneurysm(s). Historically, microsurgical clipping has been the preferred method of treatment. Endovascular treatment has been available as an alternative for the last 15 years (Guglielmi et al. 1991). Multiple platinum coils of various length and diameter are packed into the aneurysm to exclude it from the circulation. Nowadays, depending on the aneurysm's form and location as well as the expertise of the neurointerventionalist and neurosurgeon, the type of treatment is decided on a caseto-case basis.

\section{Identification of the susceptibility gene}

The two major approaches - not mutually exclusive, but complementary-are the linkage approach locating the locus of disease using families and the association approach (direct or indirect) identifying a potential disease allele in a case-control design. While linkage analysis is arguably the most powerful method for identifying a locus involving rare, high-risk alleles in Mendelian diseases, many consider genetic association analyses to be the best method for identifying genetic variants related to common and complex diseases, as is the case in IA. The HapMap project, in particular, has made genomewide association studies the most powerful tool for identification of common alleles to common disease. The recently emerged hypothesis, rare variant-common disease hypothesis, posits that several rare variants in a gene are involved in disease causality of common diseases (Cohen et al. 2004). If this is the case, an association study (even one that is genome-wide with high-density SNP genotyping) would not be able to detect the disease gene because most of the SNPs in the database are common SNPs designed to map common alleles. Therefore, both family-based genetic linkage studies as well as association studies are required for the full understanding of the genetics of IA.

\section{Chromosomal loci mapped by linkage studies}

Although the molecular basis of the disorder is not known, family studies strongly support genetic factors in the formation of IA. Several studies of familial aneurysms have identified chromosomal loci showing suggestive evidence of linkage (see Fig. 2). The mode of transmission for harboring an IA is not clear, and the genetics of the disorder appear to be complex, involving multiple loci and interaction of multiple genes (Onda et al. 2001). In accordance with this, several genomewide scans and linkage studies have identified multiple chromosomal regions (see Fig. 2) that may contain one or more susceptible genes. However, in some cases results cannot be replicated, even when examining patients of the same ethnic background (Onda et al. 2001; Yamada et al. 2003). Onda et al. observed positive evidence of linkage on chromosome 5q22-31 (MLS 2.24), 7q11 (MLS 3.22) and 14q22 (MLS 2.31) with 104 affected sib-pairs. Yamada et al. observed positive evidence of linkage on chromosome 17cen (MLS 3.00), 19q13 (MLS 2.15) and Xp22 (MLS 2.16) with 29 extended families. The inconsistency must be interpreted with caution. Discrepancies are possibly due to genetic heterogeneity and differences of patient cohorts (affected sib-pairs vs. extensive nuclear families). Further studies comprising larger sample sizes are undoubtedly needed, as multiple interacting genes and environmental factors contribute to the phenotype. Two regions that were confirmed in both samples of Japanese and white patients are on chromosome 7q (Onda et al. 2001; Olson et al. 2002) and 19q (Farnham et al. 2004; Yamada et al. 2004) (see Fig. 2). Both regions were verified once using affected sib-pairs and once using extended pedigrees. Alternatively, the rare Mendelian forms of disease might lead to the identification of genes or pathway that plays a key role in the pathogenesis of the common form of the disease. Nahed et al. identified a large family of IA (six living patients and four deceased) showing autosomal dominant inheritance and detected a single locus with a LOD score of 4.2 at chromosome 1p34.3-36.13 (Nahed et al. 2005). Positional (candidate) cloning might be underway in the locus.

A multicenter study of 26 clinical centers, which will enroll a total of 475 families with affected sib-pairs or with multiple affected relatives, has been introduced as the FIA (familial intracranial) study in a recent publication. The investigators' first goal will be to carry out a 10 -cM genome screen to identify familial IA susceptibility loci (Broderick et al. 2005). With a sample size of this magnitude, many further studies could lead to meaningful results.

\section{Candidate gene analysis}

After identifying several susceptibility loci, the search for a positional candidate gene from such a region would seem to be the logical next step towards identifying those who are predisposed to forming an IA. A host of genes has been looked at although only a few have shown moderate positive association (see Fig. 2). Conflicting results have been obtained, and no single gene has been consistently identified as a candidate gene. Obviously, many case-control studies have also focused on functional genes suspected of being involved in the disease. Of those, some play a role in connective tissue formation, such as collagen, elastin, matrix metalloproteinases and their tissue inhibitors, endoglin, and fibrillin, to name but a few. Considering the genetic role in the formation of IAs, some of the examined genes potentially possess both attributes of function and position (e.g., the elastin gene). 
Candidate gene association studies

\begin{tabular}{|c|c|c|c|c|c|c|c|c|c|}
\hline & & & & & & & & & \\
\hline & & & & Author & result & samples & $\begin{array}{l}\frac{\text { Number of }}{\text { cases vs. }} \\
\text { controls }\end{array}$ & $\frac{\text { Publication }}{\text { year }}$ & $\begin{array}{l}\frac{c \text { chromosom }}{\underline{\text { elocation }}} \\
\end{array}$ \\
\hline & & & IL-1Beta & Slowik & associated & 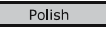 & $231 / 231$ & 2006 & 2914 \\
\hline & & & Collagen 3 & $\begin{array}{l}\text { van den } \\
\text { Berg }\end{array}$ & no association & Dutch & $41 / 41$ & 1999 & 2931 \\
\hline & & & & Brega & associated & & $19 / 15$ & 1996 & \\
\hline & & & & Kuivaniemi & & $\begin{array}{l}7 \text { different } \\
\text { nationalities }\end{array}$ & 55 patients & 1993 & \\
\hline & & & $\begin{array}{l}\text { Lysl oxidase } \\
\text { gene }\end{array}$ & & no association & $\begin{array}{c}\text { European } \\
\text { white }\end{array}$ & $25 \mathrm{FIA} /$ pub & 2004 & $5 q 23.2$ \\
\hline & & & & Yoneyama $n$ & no association & Japanese & $172 / 192$ & 2003 & \\
\hline & & & FGF1 & & & & $172 / 192$ & & 5931 \\
\hline & & & Fibrillin2 & Yoneyama $\mathrm{n}$ & no association & Japanese & $172 / 192$ & 2003 & 5q23-31 \\
\hline & & & Apolipoprotein & Roberts & associated & $\begin{array}{l}\text { Irish } \\
\text { Caucasian }\end{array}$ & $50 \mathrm{FIA} / 50$ & 2001 & 6q26-27 \\
\hline & & & Elastin & $\begin{array}{l}\text { Berthelemy- } \\
\text { Okazaki }\end{array}$ & no association & Utah white & $14 \mathrm{FIA} / \mathrm{pub}$ & 2005 & 7q11.23 \\
\hline & Linka & Ige analyses & & Krex & no association & $\begin{array}{c}\text { German } \\
\text { white }\end{array}$ & 120/172 & 2004 & \\
\hline$\frac{\text { Chromosome }}{\text { location }}$ & author & $\begin{array}{lll}\text { score } & \text { samples } & \frac{\text { Publication }}{\text { vear }}\end{array}$ & & Ruigrok & associated & & $167 / 167$ & 2004 & \\
\hline$\underline{1 p 34-36}$ & Nahed & $4.2\left(\right.$ LOD) $\quad \begin{array}{c}23 \text { kindred } \\
\text { members }\end{array} \quad 2005$ & & Hofer & no association & $\begin{array}{c}\text { European } \\
\text { white }\end{array}$ & $\begin{array}{l}30 F I A \\
+175 I A / \\
235\end{array}$ & 2003 & \\
\hline$\underline{2 p 13}$ & Roos & 3.55 (MLS) $\quad \begin{array}{c}\text { large } \\
\text { consanginous } \\
\text { pedigree }\end{array} \quad 2004$ & & Onda & $\begin{array}{c}\text { Haplotype } \\
\text { intron -20/-23 } \\
\text { associated }\end{array}$ & $\begin{array}{c}\text { Japanese sib. } \\
\text { pairs }\end{array}$ & $\begin{array}{c}78 \mathrm{FIA}+92 \mathrm{SIA} \\
/ 192\end{array}$ & 2001 & \\
\hline$\frac{\frac{5 q 22-31}{7 q 11}}{\underline{14 q 22}}$ & onda & $\begin{array}{c}2.24,3.22,2.31 \\
\text { (MLS) }\end{array} \quad \begin{array}{c}104 \text { affected } \\
\text { sibpairs }\end{array} \quad 2001$ & $\frac{\text { Collagen } 1}{\text { COL1A2) }}$ & Yoneyama & associated & Japanese & 260/293 & 2004 & 7922.1 \\
\hline 7q11 & Farnham & 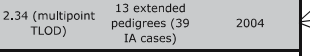 & eNOS & Akagawa & $\begin{array}{l}\text { no influence } \\
\text { on aneurysm } \\
\text { size }\end{array}$ & $\begin{array}{l}\text { Japanese/ } \\
\text { Korean }\end{array}$ & $\begin{array}{l}336 / 224(\mathrm{~J}) \\
191 / 191(\mathrm{~K})\end{array}$ & 2005 & 7936 \\
\hline$\frac{\frac{\text { linkage }}{\text { absence }}}{\underline{\underline{\text { Zq11 }}}}$ & Yamada & 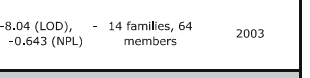 & & Khurana & $\begin{array}{l}\text { identifies IA } \\
\text { more prone to } \\
\text { rupture }\end{array}$ & Caucasian & $\begin{array}{l}\text { 58ruptured/ } \\
\text { 49unruptured }\end{array}$ & 2005 & \\
\hline $\begin{array}{c}\frac{17 c e n,}{19 q 13,} \\
\frac{19 q 22}{X p 22} \\
\end{array}$ & Yamada & $\begin{array}{ccc}\begin{array}{c}3.00,2.15,2.16 \\
\text { (MNS) }\end{array} & \begin{array}{l}29 \text { IA families } \\
\text { with }>3 \text { affected } \\
\text { individuals }\end{array} \\
\end{array}$ & & & $\begin{array}{l}\text { predicts } \\
\text { susceptibility } \\
\text { to vasospasm }\end{array}$ & Caucasian & $51 / 90$ & 2004 & \\
\hline $\begin{array}{l}\frac{\text { linkage }}{\text { absence }} \\
\underline{17 c e n} \\
\end{array}$ & Krischek & 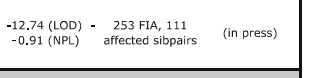 & & & $\begin{array}{c}\begin{array}{c}\text { differentistion } \\
\text { between IA } \\
\text { sizes }\end{array} \\
\end{array}$ & Caucasian & $52 / 90$ & 2003 & \\
\hline $19 q 13$ & Olson & 2.6 (MLS) $\quad 48$ sibpairs $\quad 2002$ & Endoglin & Pera & no association & Polish & $119 / 119$ & 2005 & 9q33-934.1 \\
\hline$\underline{19 q 13.3}$ & Vandervoet & 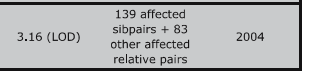 & & Peters & no association & $\begin{array}{l}\text { European } \\
\text { white }\end{array}$ & $98 / 191$ & 2005 & \\
\hline & & & & Onda & no association & Japanese & $172 / 192$ & 2003 & \\
\hline & & & & Krex & no association & $\begin{array}{c}\text { German } \\
\text { white }\end{array}$ & $121 / 124$ & 2001 & \\
\hline & & & & Takenaka & associated & Japanese & $82 / 114$ & 1999 & \\
\hline & & & SERPINA3 & Slowik & associated & Polish & $180 / 263$ & 2005 & 14932.1 \\
\hline & & & $\underline{A A T}$ & Yoneyama & no association & $\begin{array}{c}\text { Japanese/ } \\
\text { Korean }\end{array}$ & $\begin{array}{l}195 / 195(\mathrm{~J}) \\
189 / 94(\mathrm{~K})\end{array}$ & 2004 & 14932.1 \\
\hline & & & & St Jean & no association & England/USA & 72 cases & 1996 & \\
\hline & & & NADPH oxidase & Krex & no association & $\begin{array}{c}\text { German } \\
\text { white }\end{array}$ & $113 / 53$ & 2003 & $16 \mathrm{q} 24$ \\
\hline & & & $\begin{array}{l}\text { Angiotensin- } \\
\text { Enverting - } \\
\text { Enzyme }\end{array}$ & Pannu & no association & $\begin{array}{l}\text { Caucasian } \\
\text { /US }\end{array}$ & $162 / 143$ & 2005 & $17 q 23$ \\
\hline & & & & $\begin{array}{l}\text { Slowik } \\
\text { Keramatipour }\end{array}$ & $\begin{array}{l}\text { associated } \\
\text { associated } \\
\text { associated }\end{array}$ & $\begin{array}{l}\text { Polish } \\
\text { white East } \\
\text { Anglian } \\
\text { Japanese }\end{array}$ & $\begin{array}{l}90 / 128 \\
258 / 299 \\
83 / 104\end{array}$ & $\begin{array}{l}2004 \\
2000 \\
1998\end{array}$ & \\
\hline & & & MMP9 & $\begin{array}{ll}\text { Krex } & \text { R }\end{array}$ & no association & $\begin{array}{l}\text { Japanese } \\
\text { German } \\
\text { white }\end{array}$ & $\begin{array}{l}83 / 104 \\
40 / 44\end{array}$ & 2004 & $20 \mathrm{q} 11.2-$ \\
\hline & & & & & $\begin{array}{l}\text { MMP 1,3,9, } \\
12 \text { (not } \\
\text { associated) }\end{array}$ & $\begin{array}{l}\text { European } \\
\text { white }\end{array}$ & $92 / 158$ & 2001 & \\
\hline & & & & Peters & associated & $\begin{array}{l}\text { European } \\
\text { white }\end{array}$ & $98 / 191$ & 1999 & \\
\hline & & & Phospholipase C & Takenaka & not associated & Japanese & 72 cases & 1999 & 20q12-q13.1 \\
\hline & & & $\begin{array}{l}\text { Heme- } \\
\text { oxygenase } 1 \\
\end{array}$ & Morgan & associated & Caucasian & $69 / 230$ & 2005 & $22 q 13$ \\
\hline & & & IIMP 1, 2,3 & Krex & no association & $\begin{array}{c}\text { German } \\
\text { white }\end{array}$ & $44 / 44$ & 2003 & $\begin{array}{l}\text { Xpp11.3- } \\
\text { p11.23, } \\
1725, \\
22912.3 \\
\end{array}$ \\
\hline
\end{tabular}

Fig. 2 Overview of genetic studies of intracranial aneurysms: the table on the left side shows linkage studies. Gray background indicates chromosomal loci found. Right-hand table shows candidate gene association studies. Gray background if positive association was found. Arrows connect locations on the same chromosome. $L O D$ Logarithm of odds, MLS maximum LOD, $T L O D$ theta LOD, NPL non-parametric linkage analysis, $M N S$ Emphasis $>$ maximum non-parametric logarithm of the odds, FIA familial intracranial aneurysm, SIA sporadic intracranial aneurysm 
An example of conflicting results are the studies concerning the endothelial nitric oxide synthase (eNOS) gene. One study group concluded that a polymorphism of the eNOS gene correlates with the aneurysm's size, observed in Caucasian patients (Khurana et al. 2003). But this could not be replicated in a study using DNA samples of Japanese patients (Akagawa et al. 2005). It was also reported that three polymorphisms of this gene make it possible to single out patients with IAs that are more prone to rupture, comparing 58 ruptured to 49 unruptured IA cases of Caucasian origin (Khurana et al. 2005). Again, this could not be verified in a study consisting of 297 ruptured and 109 unruptured aneurysm cases of Japanese patients performed at the authors' institute (data not yet published).

As summarized in Fig. 2, thus far numerous association studies have been performed, some showing positive associations, some negative. But the majority of studies only examined small sample sizes and thus are mostly preliminary.

Among the genes that could be replicated, the elastin gene, which is located on chromosome 7q11, appears to be a highly likely candidate involved in the formation of IAs. It is located in a region that was suggestive of linkage in both Japanese and white patients from Utah (7q11). In an unpublished study, functional analysis showed the alteration of gene expression of elastin in familial IA patients.

\section{Environmental factors}

A recent meta-analysis of all longitudinal and casecontrol studies for risk factors for SAH from 1966-2005 concluded environmental risk factors to be smoking (relative risk 2.2, odds ratio 3.1) and excessive alcohol consumption (relative risk 2.1, odds ratio 1.5). A further risk factor is hypertension, showing a relative risk of 2.5 and odds ratio of 2.6. Interestingly a less robust risk factor was non-white ethnicity (relative risk 1.8, odds ratio 3.4) (Feigin et al. 2005).

Although it has still not been established whether the impact is the same as in abdominal aneurysms (Alexander 2004), inflammatory and immunological reactions may also be related to IA formation and rupture. Immunohistochemistry studies showed elevated levels of immunoreactive components in IA tissue as compared to controls (Chyatte et al. 1999; Takagi et al. 2002). A recently published hypothesis proposed that decreases in both circulating estrogen levels and cerebrovascular estrogen receptor density may contribute to an increased risk of IA pathogenesis and rupture in women during and after menopause (Harrod et al. 2006).

\section{Associations with other disorders}

Connective-tissue disorders such as polycystic kidney disease, the Ehlers-Danlos syndrome (EDS), pseudoxanthoma elasticum and fibromuscular dysplasia are associated with the presence of IA and subarachnoid hemorrhage (Schievink et al. 1994). The relative risk is increased for a ruptured aneurysm in the classic and vascular types of EDS (type I/II and IV) and autosomal dominant polycystic kidney disease (ADPKD1 and ADPKD2) (Watnick et al. 1999; Nekrysh 2000; Hademenos et al. 2001). IAs occur in about $8 \%$ of ADKPD patients (Gibbs et al. 2004) and recur frequently in ADKPD patients with known aneurysms, particularly if there is a positive family history (Ruggieri et al. 1994; Belz et al. 2003).

Grond-Ginsbach et al. found connective tissue alterations in skin biopsies of 7 (out of 21) patients with IAs. The abnormalities resembled those of EDS types II and IV, although they showed no clinical signs of a known connective-tissue disorder (GrondGinsbach et al. 2002).

\section{Concluding remarks}

Intracranial aneurysms are cerebrovascular diseases that can cause catastrophic subarachnoid hemorrhages. Several linkage regions and candidate genes showing association have been reported. Aside from genetic factors, environmental factors such as hypertension, smoking and alcohol intake are related to the pathogenesis and eventual rupture of IAs.

A single gene disorder does not seem to be involved, and a complex etiology involving multiple loci is proposed. Possibly this disease is caused by many different genes. Identification of predisposing genes may lead to a better understanding of the mechanism of IA formation. It may also allow a prediction of which individuals may be susceptible to developing an IA. Further multicenter studies comparing cohorts of patient samples of different ethnicity have to be carried out. Additional genomewide scans as well as candidate gene association studies may narrow down the responsible genetic factors and help in understanding the pathomechanism of IA formation.

Acknowledgements We wish to thank Dr. Özlem Gürvit (Department of Neuroradiology, University of Frankfurt, Germany) for providing us with the radiological images. B.K. is a Postdoctoral Fellow of the Japan Society for the Promotion of Science/Alexander von Humboldt Foundation. This study was partly supported by a Grant-in-Aid for Scientific Research on Medical Genome Science (I.I.) from the Ministry of Education, Culture, Sports, Science and Technology of Japan.

\section{References}

Akagawa H, Kasuya H, Onda H, Yoneyama T, Sasahara A, Kim CJ, Lee JC, Yang TK, Hori T, Inoue I (2005) Influence of endothelial nitric oxide synthase T-786C single nucleotide polymorphism on aneurysm size. J Neurosurg 102:68-71

Alexander JJ (2004) The pathobiology of aortic aneurysms. J Surg Res 117:163-175 
Belz MM, Fick-Brosnahan GM, Hughes RL, Rubinstein D, Chapman AB, Johnson AM, McFann KK, Kaehny WD, Gabow PA (2003) Recurrence of intracranial aneurysms in autosomaldominant polycystic kidney disease. Kidney Int 63:1824-1830

van den Berg JS, Pals G, Arwert F, Hennekam RC, Albrecht KW, Westerveld A, Limburg M (1999) Type III collagen deficiency in saccular intracranial aneurysms. Defect in gene regulation? Stroke 30:1628-1631

van den Berg JS, Limburg M, Pals G, Arwert F, Westerveld A (2001) Type III collagen deficiency in a family with intracranial aneurysms. Cerebrovasc Dis 11:92-94

Berthelemy-Okazaki N, Zhao Y, Yang Z, Camp NJ, Farnham J, Parker D, Tsuruda J, Macdonald J, Zhang K, Cannon-Albright LA (2005) Examination of ELN as a candidate gene in the Utah intracranial aneurysm pedigrees. Stroke 36:1283-1284

Brega KE, Seltzer WK, Munro LG, Breeze RE (1996) Genotypic variations of type III collagen in patients with cerebral aneurysms. Surg Neurol 46:253-256; discussion 256-257

Broderick JP, Brott T, Tomsick T, Huster G, Miller R (1992) The risk of subarachnoid and intracerebral hemorrhages in blacks as compared with whites. N Engl J Med 326:733-736

Broderick JP, Sauerbeck LR, Foroud T, Huston J 3rd, Pankratz N, Meissner I, Brown RD Jr (2005) The Familial Intracranial Aneurysm (FIA) study protocol. BMC Med Genet 6:17

Bromberg JE, Rinkel GJ, Algra A, Greebe P, van Duyn CM, Hasan D, Limburg M, ter Berg HW, Wijdicks EF, van Gijn J (1995) Subarachnoid haemorrhage in first and second degree relatives of patients with subarachnoid haemorrhage. BMJ 311:288-289

Chyatte D, Reilly J, Tilson MD (1990) Morphometric analysis of reticular and elastin fibers in the cerebral arteries of patients with intracranial aneurysms. Neurosurgery 26:939-943

Chyatte D, Bruno G, Desai S, Todor DR (1999) Inflammation and intracranial aneurysms. Neurosurgery 45:1137-1146; discussion $1146-1147$

Cohen JC, Kiss RS, Pertsemlidis A, Marcel YL, McPherson R, Hobbs HH (2004) Multiple rare alleles contribute to low plasma levels of HDL cholesterol. Science 305:869-872

Crompton MR (1966) The pathogenesis of cerebral aneurysms. Brain 89:797-814

De Braekeleer M, Perusse L, Cantin L, Bouchard JM, Mathieu J (1996) A study of inbreeding and kinship in intracranial aneurysms in the Saguenay Lac-Saint-Jean region (Quebec, Canada). Ann Hum Genet 60(Pt. 2):99-104

Farnham JM, Camp NJ, Neuhausen SL, Tsuruda J, Parker D, MacDonald J, Cannon-Albright LA (2004) Confirmation of chromosome $7 \mathrm{q} 11$ locus for predisposition to intracranial aneurysm. Hum Genet 114:250-255

Feigin VL, Rinkel GJ, Lawes CM, Algra A, Bennett DA, van Gijn J, Anderson CS (2005) Risk factors for subarachnoid hemorrhage: an updated systematic review of epidemiological studies. Stroke 36:2773-2780

Finlay HM, Whittaker P, Canham PB (1998) Collagen organization in the branching region of human brain arteries. Stroke 29:1595-1601

Fujimoto K (1996) 'Medial defects' in the prenatal human cerebral arteries: an electron microscopic study. Stroke 27:706-708

Gibbs GF, Huston J 3rd, Qian Q, Kubly V, Harris PC, Brown RD Jr, Torres VE (2004) Follow-up of intracranial aneurysms in autosomal-dominant polycystic kidney disease. Kidney Int 65:1621-1627

Grond-Ginsbach C, Schnippering H, Hausser I, Weber R, Werner I, Steiner HH, Luttgen N, Busse O, Grau A, Brandt T (2002) Ultrastructural connective tissue aberrations in patients with intracranial aneurysms. Stroke 33:2192-2196

Guglielmi G, Vinuela F, Dion J, Duckwiler G (1991) Electrothrombosis of saccular aneurysms via endovascular approach. Part 2: preliminary clinical experience. J Neurosurg 75:8-14

Hademenos GJ, Alberts MJ, Awad I, Mayberg M, Shepard T, Jagoda A, Latchaw RE, Todd HW, Viste K, Starke R, Girgus MS, Marler J, Emr M, Hart N (2001) Advances in the genetics of cerebrovascular disease and stroke. Neurology 56:997-1008
Harrod CG, Batjer HH, Bendok BR (2006) Deficiencies in estrogen-mediated regulation of cerebrovascular homeostasis may contribute to an increased risk of cerebral aneurysm pathogenesis and rupture in menopausal and postmenopausal women. Med Hypotheses 66(4):736-756

Hofer A, Hermans M, Kubassek N, Sitzer M, Funke H, Stogbauer F, Ivaskevicius V, Oldenburg J, Burtscher J, Knopp U, Schoch B, Wanke I, Hubner F, Deinsberger W, Meyer B, BoecherSchwarz H, Poewe W, Raabe A, Steinmetz H, Auburger G (2003) Elastin polymorphism haplotype and intracranial aneurysms are not associated in Central Europe. Stroke 34:12071211

Hofer A, Ozkan S, Hermans M, Kubassek N, Sitzer M, Burtscher J, Knopp U, Schoch B, Wanke I, Huebner F, Raabe A, Steinmetz H, Auburger G (2004) Mutations in the lysyl oxidase gene not associated with intracranial aneurysm in Central European families. Cerebrovasc Dis 18:189-193

Inagawa $\mathrm{T}$, Ishikawa $\mathrm{S}$, Aoki $\mathrm{H}$, Takahashi $\mathrm{M}$, Yoshimoto $\mathrm{H}$ (1988) Aneurysmal subarachnoid hemorrhage in Izumo City and Shimane Prefecture of Japan. Incidence. Stroke 19:170-175

Ingall TJ, Whisnant JP, Wiebers DO, O'Fallon WM (1989) Has there been a decline in subarachnoid hemorrhage mortality? Stroke 20:718-724

Ingebrigtsen T, Morgan MK, Faulder K, Ingebrigtsen L, Sparr T, Schirmer H (2004) Bifurcation geometry and the presence of cerebral artery aneurysms. J Neurosurg 101:108-113

Iwamoto H, Kiyohara Y, Fujishima M, Kato I, Nakayama K, Sueishi K, Tsuneyoshi M (1999) Prevalence of intracranial saccular aneurysms in a Japanese community based on a consecutive autopsy series during a 30 -year observation period. The Hisayama Study. Stroke 30:1390-1395

Juvela S (2002) Natural history of unruptured intracranial aneurysms: risks for aneurysm formation, growth, and rupture. Acta Neurochir Suppl 82:27-30

Keramatipour M, McConnell RS, Kirkpatrick P, Tebbs S, Furlong RA, Rubinsztein DC (2000) The ACE I allele is associated with increased risk for ruptured intracranial aneurysms. J Med Genet 37:498-500

Khurana VG, Sohni YR, Mangrum WI, McClelland RL, O'Kane DJ, Meyer FB, Meissner I (2003) Endothelial nitric oxide synthase T-786C single nucleotide polymorphism: a putative genetic marker differentiating small versus large ruptured intracranial aneurysms. Stroke 34:2555-2559

Khurana VG, Meissner I, Meyer FB (2004) Update on genetic evidence for rupture-prone compared with rupture-resistant intracranial saccular aneurysms. Neurosurg Focus 17:E7

Khurana VG, Meissner I, Sohni YR, Bamlet WR, McClelland RL, Cunningham JM, Meyer FB (2005) The presence of tandem endothelial nitric oxide synthase gene polymorphisms identifying brain aneurysms more prone to rupture. J Neurosurg 102:526-531

Kiyohara Y, Ueda K, Hasuo Y, Wada J, Kawano H, Kato I, Sinkawa A, Ohmura T, Iwamoto H, Omae T, et al (1989) Incidence and prognosis of subarachnoid hemorrhage in a Japanese rural community. Stroke 20:1150-1155

Kojima M, Nagasawa S, Lee YE, Takeichi Y, Tsuda E, Mabuchi N (1998) Asymptomatic familial cerebral aneurysms. Neurosurgery 43:776-781

Krex D, Ziegler A, Schackert HK, Schackert G (2001) Lack of association between endoglin intron 7 insertion polymorphism and intracranial aneurysms in a white population: evidence of racial/ethnic differences. Stroke 32:2689-2694

Krex D, Rohl H, Konig IR, Ziegler A, Schackert HK, Schackert G (2003a) Tissue inhibitor of metalloproteinases-1, -2, and -3 polymorphisms in a white population with intracranial aneurysms. Stroke 34:2817-2821

Krex D, Ziegler A, Konig IR, Schackert HK, Schackert G (2003b) Polymorphisms of the NADPH oxidase P22PHOX gene in a Caucasian population with intracranial aneurysms. Cerebrovasc Dis 16:363-368

Krex D, Konig IR, Ziegler A, Schackert HK, Schackert G (2004a) Extended single nucleotide polymorphism and haplotype 
analysis of the elastin gene in Caucasians with intracranial aneurysms provides evidence for racially/ethnically based differences. Cerebrovasc Dis 18:104-110

Krex D, Kotteck K, Konig IR, Ziegler A, Schackert HK, Schackert G (2004b) Matrix metalloproteinase-9 coding sequence singlenucleotide polymorphisms in Caucasians with intracranial aneurysms. Neurosurgery 55:207-212; discussion 212-213

Krischek B, Narita A, Akagawa H, Kasuya H, Tajima A, Onda H, Yoneyama T, Hori T, Inoue I (2006) Is there any evidence for linkage on chromosome 17cen in affected Japanese sib-pairs with an intracranial aneurysm? J Hum Genet (in press)

Kuivaniemi H, Prockop DJ, Wu Y, Madhatheri SL, Kleinert C, Earley JJ, Jokinen A, Stolle C, Majamaa K, Myllyla VV, et al (1993) Exclusion of mutations in the gene for type III collagen (COL3A1) as a common cause of intracranial aneurysms or cervical artery dissections: results from sequence analysis of the coding sequences of type III collagen from 55 unrelated patients. Neurology 43:2652-2658

Morgan L, Hawe E, Palmen J, Montgomery H, Humphries SE, Kitchen N (2005) Polymorphism of the heme oxygenase-1 gene and cerebral aneurysms. Br J Neurosurg 19:317-321

Morita A, Fujiwara S, Hashi K, Ohtsu H, Kirino T (2005) Risk of rupture associated with intact cerebral aneurysms in the Japanese population: a systematic review of the literature from Japan. J Neurosurg 102:601-606

Nahed BV, Seker A, Guclu B, Ozturk AK, Finberg K, Hawkins AA, DiLuna ML, State M, Lifton RP, Gunel M (2005) Mapping a Mendelian form of intracranial aneurysm to 1p34.3p36.13. Am J Hum Genet 76:172-179

Nakagawa T, Hashi K (1994) The incidence and treatment of asymptomatic, unruptured cerebral aneurysms. J Neurosurg $80: 217-223$

Nekrysh SY (2000) Association between heritable connective tissue disorders and intracranial aneurysms. Surg Neurol 54:77-78

Olson JM, Vongpunsawad S, Kuivaniemi H, Ronkainen A, Hernesniemi J, Ryynanen M, Kim LL, Tromp G (2002) Search for intracranial aneurysm susceptibility gene(s) using Finnish families. BMC Med Genet 3:7

Onda H, Kasuya H, Yoneyama T, Takakura K, Hori T, Takeda J, Nakajima T, Inoue I (2001) Genomewide-linkage and haplotype-association studies map intracranial aneurysm to chromosome 7q11. Am J Hum Genet 69:804-819

Onda $\mathrm{H}$, Kasuya $\mathrm{H}$, Yoneyama $\mathrm{T}$, Hori T, Nakajima T, Inoue I (2003) Endoglin is not a major susceptibility gene for intracranial aneurysm among Japanese. Stroke 34:1640-1644

Pannu H, Kim DH, Seaman CR, Van Ginhoven G, Shete S, Milewicz DM (2005) Lack of an association between the angiotensin-converting enzyme insertion/deletion polymorphism and intracranial aneurysms in a Caucasian population in the United States. J Neurosurg 103:92-96

Pera J, Slowik A, Dziedzic T, Borratynska A, Rog TM, Betlej M, Czepko R, Szczudlik A (2005) Endoglin gene insertion polymorphism not associated with aneurysmal subarachnoid hemorrhage. J Neurosurg 102:879-881

Peters DG, Kassam A, St Jean PL, Yonas H, Ferrell RE (1999) Functional polymorphism in the matrix metalloproteinase-9 promoter as a potential risk factor for intracranial aneurysm. Stroke 30:2612-2616

Peters DG, Kassam AB, Chang YF (2005) A DNA sequence polymorphism in the endoglin gene is not associated with intracranial aneurysm or aneurysmal subarachnoid hemorrhage. Cerebrovasc Dis 20:96-100

Rinkel GJ, Djibuti M, Algra A, van Gijn J (1998) Prevalence and risk of rupture of intracranial aneurysms: a systematic review. Stroke 29:251-256

Roberts GA, Corcoran BT, Pfouts LL, Phillips JP, Farrell MA, Bouchier-Hayes DJ, Collins PB (2001) Genetic evaluation of lipoprotein(a) in intracranial aneurysm disease. Neurosurgery 49:133-140; discussion 141-142

Ronkainen A, Hernesniemi J, Puranen M, Niemitukia L, Vanninen R, Ryynanen M, Kuivaniemi H, Tromp G (1997) Familial intracranial aneurysms. Lancet 349:380-384
Roos YB, Pals G, Struycken PM, Rinkel GJ, Limburg M, Pronk JC, van den Berg JS, Luijten JA, Pearson PL, Vermeulen M, Westerveld A (2004) Genome-wide linkage in a large Dutch consanguineous family maps a locus for intracranial aneurysms to chromosome 2p13. Stroke 35:2276-2281

Ruggieri PM, Poulos N, Masaryk TJ, Ross JS, Obuchowski NA, Awad IA, Braun WE, Nally J, Lewin JS, Modic MT (1994) Occult intracranial aneurysms in polycystic kidney disease: screening with MR angiography. Radiology 191:33-39

Ruigrok YM, Seitz U, Wolterink S, Rinkel GJ, Wijmenga C, Urban Z (2004) Association of polymorphisms and haplotypes in the elastin gene in Dutch patients with sporadic aneurysmal subarachnoid hemorrhage. Stroke 35:2064-2068

Schievink WI, Michels VV, Piepgras DG (1994) Neurovascular manifestations of heritable connective tissue disorders. A review. Stroke 25:889-903

Schievink WI, Schaid DJ, Michels VV, Piepgras DG (1995) Familial aneurysmal subarachnoid hemorrhage: a communitybased study. J Neurosurg 83:426-429

Slowik A, Borratynska A, Pera J, Betlej M, Dziedzic T, Krzyszkowski T, Czepko R, Figlewicz DA, Szczudlik A (2004) II genotype of the angiotensin-converting enzyme gene increases the risk for subarachnoid hemorrhage from ruptured aneurysm. Stroke 35:1594-1597

Slowik A, Borratynska A, Turaj W, Pera J, Dziedzic T, Figlewicz DA, Betlej M, Krzyszkowski T, Czepko R, Szczudlik A (2005) Alpha1-antichymotrypsin gene (SERPINA3) A/T polymorphism as a risk factor for aneurysmal subarachnoid hemorrhage. Stroke 36:737-740

Slowik A, Borratynska A, Turaj W, Pera J, Dziedzic T, Wloch D, Szczudlik A, Betlej M, Krzyszkowski T, Czepko R (2006) Interleukin 1beta-511 C/T polymorphism and risk of aneurysmal subarachnoid haemorrhage. J Neurol Neurosurg Psychiatry 77:279-280

Stehbens WE (1989) Etiology of intracranial berry aneurysms. J Neurosurg 70:823-831

Takagi Y, Ishikawa M, Nozaki K, Yoshimura S, Hashimoto N (2002) Increased expression of phosphorylated c-Jun aminoterminal kinase and phosphorylated c-Jun in human cerebral aneurysms: role of the c-Jun amino-terminal kinase/c-Jun pathway in apoptosis of vascular walls. Neurosurgery 51:9971002; discussion 1002-1004

Takenaka K, Yamakawa H, Sakai H, Yoshimura S, Murase S, Okumura A, Nakatani K, Kimura T, Nishimura Y, Yoshimi N, Sakai N (1998) Angiotensin I-converting enzyme gene polymorphism in intracranial saccular aneurysm individuals. Neurol Res 20:607-611

Takenaka K, Sakai H, Yamakawa H, Yoshimura S, Kumagai M, Nakashima S, Nozawa Y, Sakai N (1999) Polymorphism of the endoglin gene in patients with intracranial saccular aneurysms. J Neurosurg 90:935-938

Ujiie H, Sato K, Onda H, Oikawa A, Kagawa M, Takakura K, Kobayashi N (1993) Clinical analysis of incidentally discovered unruptured aneurysms. Stroke 24:1850-1856

van der Voet M, Olson JM, Kuivaniemi H, Dudek DM, Skunca M, Ronkainen A, Niemela M, Jaaskelainen J, Hernesniemi J, Helin $\mathrm{K}$, Leinonen E, Biswas M, Tromp G (2004) Intracranial aneurysms in Finnish families: confirmation of linkage and refinement of the interval to chromosome 19q13.3. Am J Hum Genet 74:564-571

Wang PS, Longstreth WT Jr, Koepsell TD (1995) Subarachnoid hemorrhage and family history. A population-based case-control study. Arch Neurol 52:202-204

Wardlaw JM, White PM (2000) The detection and management of unruptured intracranial aneurysms. Brain 123(Pt. 2):205-221

Watnick T, Phakdeekitcharoen B, Johnson A, Gandolph M, Wang M, Briefel G, Klinger KW, Kimberling W, Gabow P, Germino GG (1999) Mutation detection of PKD1 identifies a novel mutation common to three families with aneurysms and/or very-early-onset disease. Am J Hum Genet 65:1561-1571

White PM, Wardlaw J (2003) Unruptured intracranial aneurysms: prospective data have arrived. Lancet 362:90-91 
Wiebers DO, Whisnant JP, Huston J 3rd, Meissner I, Brown RD Jr, Piepgras DG, Forbes GS, Thielen K, Nichols D, O'Fallon WM, Peacock J, Jaeger L, Kassell NF, Kongable-Beckman GL, Torner JC (2003) Unruptured intracranial aneurysms: natural history, clinical outcome, and risks of surgical and endovascular treatment. Lancet 362:103-110

Yamada S, Utsunomiya $\mathrm{M}$, Inoue $\mathrm{K}$, Nozaki $\mathrm{K}$, Miyamoto $\mathrm{S}$, Hashimoto N, Takenaka K, Yoshinaga T, Koizumi A (2003) Absence of linkage of familial intracranial aneurysms to $7 \mathrm{q} 11$ in highly aggregated Japanese families. Stroke 34:892-900

Yamada S, Utsunomiya M, Inoue K, Nozaki K, Inoue S, Takenaka K, Hashimoto N, Koizumi A (2004) Genome-wide scan for Japanese familial intracranial aneurysms: linkage to several chromosomal regions. Circulation 110:3727-3733

Yamaki T, Tanabe S, Takamura Y, Yamamura A, Ochi S, Nakagawa T, Hashi K (1994) Cerebellar infarcts that require differentiation from tumors: diagnosis with MRI. No Shinkei Geka 22:349-352

Yoneyama T, Kasuya $\mathrm{H}$, Onda $\mathrm{H}$, Akagawa $\mathrm{H}$, Jinnai $\mathrm{N}$, Nakajima T, Hori T, Inoue I (2003) Association of positional and functional candidate genes FGF1, FBN2, and LOX on 5q31 with intracranial aneurysm. J Hum Genet 48:309314

Yoneyama T, Kasuya H, Akagawa H, Onda H, Nakajima T, Hori T, Inoue I, Lee JC, Yang TK, Kim CJ (2004a) Absence of alpha-1 antitrypsin deficiency alleles ( $\mathrm{S}$ and $\mathrm{Z}$ ) in Japanese and Korean patients with aneurysmal subarachnoid hemorrhage. Stroke 35:e376-e378

Yoneyama $\mathrm{T}$, Kasuya $\mathrm{H}$, Onda $\mathrm{H}$, Akagawa $\mathrm{H}$, Hashiguchi $\mathrm{K}$, Nakajima T, Hori T, Inoue I (2004b) Collagen type I alpha2 (COL1A2) is the susceptible gene for intracranial aneurysms. Stroke 35:443-448

Yoshimoto T, Mizoi K (1997) Importance of management of unruptured cerebral aneurysms. Surg Neurol 47:522-525; discussion 525-526

Zhang B, Dhillon S, Geary I, Howell WM, Iannotti F, Day IN, Ye S (2001) Polymorphisms in matrix metalloproteinase-1, -3, -9, and -12 genes in relation to subarachnoid hemorrhage. Stroke 32:2198-2202 